\title{
Investigating the genetic polymorphism in the exon 2 region of ovine beta-lactoglobulin gene and its association with some milk traits
}

\author{
Özge ÖZMEN ${ }^{1}$, Selim KUL ${ }^{2}$ \\ ${ }^{1}$ Ankara University, Faculty of Veterinary Medicine, Department of Genetics, Ankara; ${ }^{2}$ Frrat University, Faculty of Veterinary \\ Medicine, Department of Animal Breeding, Elazı̆g, Turkey.
}

\begin{abstract}
Summary: $\beta$-lactoglobulin $(\beta-L G B)$ gene is the major whey protein of ruminant and is synthesized by secreting cells of mammary gland during pregnancy and lactation and its biological function is still unclear. Therefore, the purpose of the study was to identify genotype frequencies of single nucleotide polymorphisms (SNPs) in ovine $\beta$ - LGB gene exon 2 region and its possible association with milk traits in dairy sheep breeds. The genetic structures of the SNPs were examined by PCR-RFLP and DNA sequencing in three sheep populations. A hundred fifty blood and milk samples each from Sakiz, Akkaraman and Awassi ewes, with total of 450 samples were used in the experiment. Awassi sheep breed was found as monomorphic for $\beta$ - $L G B$ gene in exon 2 region. Genotype $\mathrm{AB}$ showed a strong association with milk yields content $(\mathrm{P}<0.001)$, whereas the animals carrying AA genotype had a higher fat percentage $(\mathrm{P}<0.001)$ value in the Sakiz sheep breeds. Furthermore, we have reported for the first time g. 121C $>$ A SNPs of the $\beta-L G B$ gene for exon 2. In this research, $\beta-L G B$ showed a significant effect on milk yield in the Sakiz ewes, but further studies are necessary to confirm the association reported here.
\end{abstract}

Keywords: $\beta$-lactoglobulin $(\beta$ - $L G B)$, milk production traits, sheep.

\section{Koyun beta-laktoglobulin geni ekzon 2 bölgesine ait genetik polimorfizmin araştırılması ve bazı süt verim özellikleri ile ilişkisi}

Özet: $\beta$-laktoglobulin $(\beta-L G B)$ geni ruminantlarda en temel peynir altı suyu protenidir; gebelik ve laktasyon süresince meme bezi hücrelerinden salgılanmaktadır; biyolojik fonksiyonu ise henüz tam olarak bilinmemektedir. Dolayısıyla, bu çalışmanın amacı koyun $\beta$-LGB geni ekzon 2 bölgesine ait tek nükleotit polimorfizmlerinin (TNP) genotip frekanslarının saptanması ve bu olası TNP'lerin süt verim özellikleri ile ilişkisinin belirlenmesidir. Çalışmada üç koyun popülasyonunda belirlenen TNP'lerin genetik yapısı PCR-RFLP ve DNA dizi analizi metodu ile incelenmiştir. Araştırmada toplam 450 örnek olmak üzere Sakız, Akkaraman ve İvesi ırkı koyunlardan 150'şer adet kan ve süt örneği kullanılmıştır. İvesi koyun ırkı $\beta$ - $L G B$ geni ekzon 2 bölgesi için monomorfik bulunmuştur. Sakız koyun ırkında $\mathrm{AB}$ genotipi ile süt verimi arasında önemli bir ilişki bulunurken $(\mathrm{P}<0.001)$, AA genotipli bireylerin yüksek yağ yüzdesine $(\mathrm{P}<0.001)$ sahip olduğu gözlenmiştir. Ayrıca bu çalışmada, $\beta$ - $L G B$ geni ekzon 2 bölgesine ait g.121C $>\mathrm{A}$ SNP ilk kez tanımlanmıştır. Bu araştırmada, Sakız koyun ırkında $\beta$-LGB geninin süt verimi üzerine önemli bir etkisi olduğu belirlenmiştir, ancak elde edilen bu bulguların bu konuda yapılacak ilişkilendirme çalışmaları ile doğrulanması gerekmektedir.

Anahtar sözcükler: $\beta$-laktoglobulin $(\beta$ - LGB), koyun, süt verim özellikleri.

\section{Introduction}

The dairy sheep industry plays a vital role in many Mediterranean countries, especially for the production of high quality cheese from local dairy breeds $(6,23)$. In the last few years, interest concerning the milk from small ruminants has been increasing in order to find new ways of exploiting the potential of local breeds (33). According to FAO, total sheep milk production of Turkey was 1.101.013 tons in 2013 and the number of sheep was 27.425.233 heads in 2013 (14). In Turkey, sheep breeds are generally multipurpose, reared for meat and milk production (36) and dairy sheep have been farmed traditionally, almost all milk is used for cheese production and, consequently, milk content traits are very important (6).

For the identification and characterization of genetic variants associated with milk performance traits in various sheep breeds, many research efforts have been based on the candidate gene approach $(22,23,28,34)$. Because of financial and practical restrictions, genomewide selection is usually unfeasible for most dairy sheep breeds, making the application of selection schemes assisted by molecular information on causal mutations of genes affecting milk traits an attractive alternative in dairy sheep $(6,24)$. Polymorphisms within selected candidate genes can be tested for their associations with 
quantitative traits to better understand their effects and can be used in marker-assisted selection (37).

Most association studies between the ovine milk protein polymorphisms and the milk performance traits have assessed mainly the effects of single gene and some controversial results have been revealed $(2,4,5,9)$. Furthermore, typing autochthonous sheep breeds at milk protein loci gives the possibility of increasing productivity and avoiding the loss of genetic variability, thus preserving biodiversity with particular attention to endangered breeds carrying special milk protein variants (33).

$\beta$-lactoglobulin $(\beta-L G B)$ gene is the major whey protein of ruminant and is synthesized by secreting cells of mammary gland during pregnancy and lactation. Although its biological function is still unclear, $\beta-L G B$ provides amino acids to the offspring and a possible role in the transport of retinol and fatty acids has been suggested. $\beta-L G B$ gene is located on ovine chromosome 3 and is one of the specific genes that affect milk traits. Three co-dominant alleles have been previously described in sheep. The A and B variants are presented in all breeds, but the $\mathrm{C}$ variant is a rare allele found in the Merino breed (33). The genetic variant A differs from variant $\mathrm{B}$ in the amino acid sequence at position 20 (Tyr20 $\rightarrow$ His20); as reported by Erhardt (12). Mapping quantitative trait loci for milk production and genetic polymorphisms of milk proteins in dairy sheep. While the variant $\mathrm{A}$ of $\beta-L G B$ seems to be associated with fat and protein, variant $B$ is associated with higher milk yield (33).

Based on the above considerations, the objective of this study is to detect possible ovine $\beta-L G B$ genotypes, and its possible association with milk production traits in Sakiz, Akkaraman and Awassi sheep breeds.

\section{Material and Methods}

Animal resources and DNA isolation: Sakiz is a high milk yield local dairy sheep breed in Turkey and is well known for its early sexual maturity and outstanding prolificacy. Milk production varies from 120-250 kg for 175 days lactation length depending on management and husbandry conditions. Akkaraman is the largest local sheep population bred in Turkey. It's fat tailed sheep and bred as a dual purpose breed with milk production varying from $50-60 \mathrm{~kg}$ per 140 days lactation. Awassi is principally a milk breed reared in southeastern in Turkey. Its milk production varies from $120-160 \mathrm{~kg}$ per 165 days lactation (1).

Four hundred and fifty blood and milk samples were used in in the study which included a set of three 150 samples from Sakiz, Akkaraman and Awassi ewes respectively. The sample selected randomly consisted of animals that were 4 years old, multiparous and lactating.
Akkaraman, Awassi and Sakiz breeds were reared, respectively, in Elazig and Balikesir County at the commercial herds of three farms. Animals were fed $250 \mathrm{~g} / \mathrm{head} /$ day concentrate commercial food (crude protein $20 \%$ and $2500 \mathrm{ME} \mathrm{kcal} / \mathrm{kg}$ ) as supplement and raised in semi-intensive conditions. Measurements of milk yield were initiated on the $14^{\text {th }}$ day of lactation to exclude the risk of contamination with colostrum. Animals were milked twice a day at constant intervals and $20 \mathrm{ml}$ milk sample was collected for milk analysis. Individual milk yield was recorded every day during lactation for each individual and each breed. Milk sample was analysed for milk composition (fat, protein, density and non-fat solids) using Lactoscan milk analyser (Milktronic Company, Nova Zagora, Bulgaria). Jugular blood samples (2 ml/ewe) were collected aseptically from each of the animals, using EDTA as an anticoagulant. Genomic DNA was extracted from the whole blood using the phenol chloroform method (30). All samples were delivered back to the laboratory in icebox.

The study was approved by the Ethical Committee of Laboratory Animals, Firat University, (FUHADEK2012/06.65).

DNA amplification and genotyping: For this study, DNA samples were amplified for $\beta-L G B$ gene and thereafter digested with $R s a I$ restriction enzyme as described by Feligini et al. (15). PCR reaction was carried out in $25 \mu \mathrm{L}$ of total volume, containing $10 \mathrm{X}$ PCR buffer (50 mM/L KCl, $10 \mathrm{mM} / \mathrm{L}$ Tris- $\mathrm{HCl}$ ( $\mathrm{pH} 8.0)$, $0.1 \%$ Triton $\mathrm{X}-100), 2.5 \mathrm{mM} \mathrm{MgCl}_{2}, 0.2 \mathrm{mM}$ of each $\mathrm{dNTP}, 10 \mathrm{pM} / \mathrm{L}$ of each primer, $50 \mathrm{ng}$ ovine genomic DNA and 1U Taq DNA polymerase. PCR conditions were as follows: denaturation at $94{ }^{\circ} \mathrm{C}$ for $4 \mathrm{~min}$, followed by 34 cycles of denaturation at $94{ }^{\circ} \mathrm{C}$ for 30 sec, annealing at $58{ }^{\circ} \mathrm{C}$ for $30 \mathrm{sec}$, extention at $72{ }^{\circ} \mathrm{C}$ for $30 \mathrm{sec}$ and final extention at $72{ }^{\circ} \mathrm{C}$ for $4 \mathrm{~min}$, on Mastercycler ${ }^{\circledR}$ (Eppendorf AG, Hamburg, Germany). The PCR products were separated by electrophoresis on $3 \%$ MetaPhor agarose gels in parallel with a $100 \mathrm{bp}$ DNA marker.

Allele A contained 2 restriction sites for $R s a \mathrm{I}$ and resulted 3 fragments of 66,37 and $17 \mathrm{bp}$, whereas the absence of one restriction site in the $\mathrm{B}$ allele resulted in only 2 fragments of 103 and $17 \mathrm{bp}$. Then, fifteen randomly chosen PCR samples of each genotype were sequenced from both directions to confirm the results obtained with PCR-RFLP technique. Direct sequencing was performed on 3100 ABI PRISM sequencer (Applied Bio-systems, USA) and sequenced by commercial services. Sequences were obtained with the same primers used for PCR amplification. Obtained sequences were aligned with the X12817 for $\beta-L G B$ sequence of the GenBank. 
Statistical Analysis: The genotype, allelic frequencies and the observed and expected heterozygosity and Hardy-Weinberg equilibrium were calculated using Arlequin ver 3.5.1.3 package program (13). Sequences were analyzed using the BIOEDIT ver 7.2.5 software (18) for sequence alignment.

Statistical analysis was performed using R-Project software (R Core Team, 2013) and general linear mixed model (GLMM) was applied to analyse association between $\beta$ - $L G B$ variants and milk yield, fat and protein percentages. Dependent variables in the analysis were milk yield, fat and protein percentage whereas the $\beta-L G B$ genotypes and breed were considered as fixed effects in the model. The model used was as follows:

$$
Y_{i j k l}=\mu+B_{i}+G_{j}+G x B_{k}+A_{l}+e
$$

where $Y$ is the variable being estimated being test day milk yield, fat or protein; $B_{i}$ is the fixed effect of the breed; $G_{j}$ is the fixed effect of the genotype; $G x B_{k}$ is the fixed interaction effect of breed and genotype; $A_{l}$ is the random effect of the animal and $e$ is the residual effect.

\section{Results}

Genotypic and allelic frequencies: After digestion of the $120 \mathrm{bp}$ fragment of $\beta-L G B$ gene with the $R s a \mathrm{I}$ endonuclease three genotypes were identified in examined breeds; AA (66, 37 and 17 bp), AB (103, 66, 37 and $17 \mathrm{bp}$ ) and BB (103 and $17 \mathrm{bp}$ ) (Figure 1). Allelic frequencies for Sakiz, Akkaraman and Awassi breeds were $0.90,0.98$ and 1 respectively for allele A; 0.10, 0.02 and 0 respectively for allele $B$. As a result, genotype $A B$ and $\mathrm{BB}$ were not shown in Awassi sheep breed and it was found as monomorphic for $\beta$ - $L G B$ gene in exon 2 region. The genotype frequency was different between Sakiz and Akkaraman breeds. AB genotype frequency was found higher in Sakiz breeds, whereas BB genotype was only shown in Akkaraman breed. The allele distribution of $\beta-L G B$ gene in Sakiz sheep breeds was in agreement with Hardy-Weinberg equilibrium by the Chisquare test, on the contrary Akkaraman breed was not agreement with Hardy-Weinberg equilibrium (Table 1).

Allele and genotype effects on milk production traits: Least squared means of milk traits are represented in Table 2. As milk analyze results, milk yield, fat, protein and lactose percentage were found as statistically important. Sakiz sheep breed has shown highest milk yield, protein and fat percentage, Akkaraman sheep breed has highest lactose percentage values when compared to among sheep breeds.

Results of the association study of $\beta-L G B$ genotypes with milk production traits are shown in Table 3 . In this

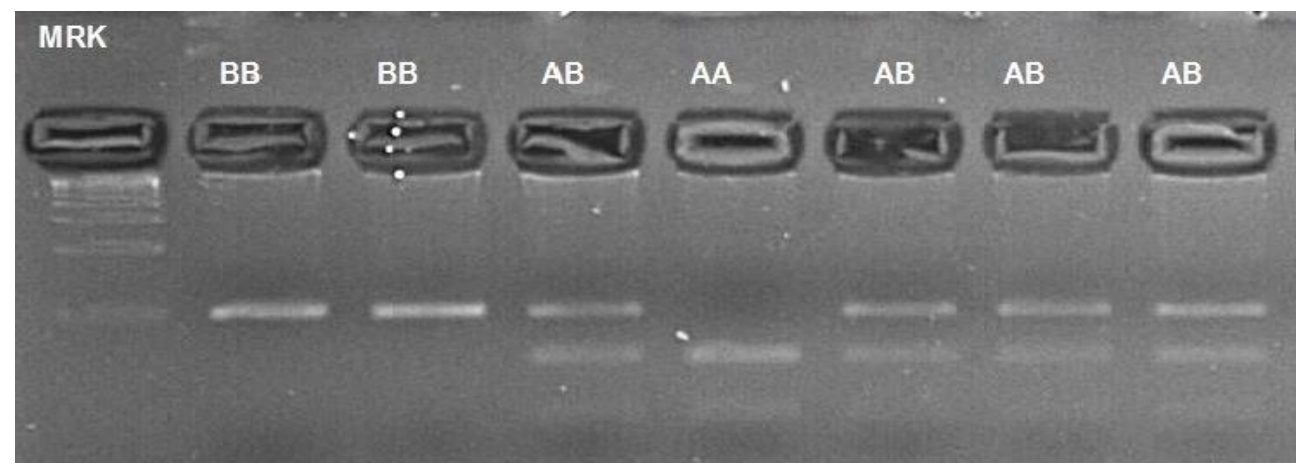

Figure 1. MetaPhor Agarose gel electrophoresis band patterns after digestion with RsaI endonuclease within the exon 2 region sequence of the sheep $\beta-L G B$ gene; Lane MRK:100 bp DNA marker; Lane 2-3: BB genotype ; Lane 4,6-8: AB genotype; Lane 5: AA genotype.

Şekil 1. Koyun $\beta-L G B$ geni exon 2 bölgesinin RsaI endonükleazı ile kesimi sonrası elde edilen bant paternlerine ait MetaPhor Agaroz jel elektroforez görüntüsü; 1. Kuyucuk MRK: 100 bç DNA marker; 2-3. Kuyucuklar: BB genotipi; 4,6-8. Kuyucuklar: AB genotipi; 5. Kuyucuk: AA genotipi.

Table 1. Distribution of the observed allele frequencies for $\beta$-LGB loci, expected genotype frequencies in accordance with HardyWeinberg equilibrium, observed $\left(\mathrm{H}_{\mathrm{O}}\right)$ and expected heterozygosity $\left(\mathrm{H}_{\mathrm{E}}\right)$ in Sakiz (SAK), Akkaraman (AKK) and Awassi (AWS) sheep breeds.

Tablo 1. Sakız (SAK), Akkaraman (AKK) ve İvesi (AWS) koyun ırklarında $\beta$ - LGB lokusu için gözlenen alel frekansı dağıllımı, Hardy-Weinberg dengesi ile uyumlu olarak beklenen genotip frekansı, gözlenen $\left(\mathrm{H}_{\mathrm{O}}\right)$ ve beklenen heterozigotluk $\left(\mathrm{H}_{\mathrm{E}}\right)$ dağılımları.

\begin{tabular}{|c|c|c|c|c|c|c|c|c|c|}
\hline \multirow[b]{2}{*}{ Population } & \multirow[b]{2}{*}{$\mathrm{n}$} & \multicolumn{2}{|c|}{ Allele frequency } & \multicolumn{3}{|c|}{ Observed Genotypes } & \multirow[b]{2}{*}{$P$ value } & \multirow[b]{2}{*}{$\mathrm{H}_{\mathrm{O}}$} & \multirow[b]{2}{*}{$\mathrm{H}_{\mathrm{E}}$} \\
\hline & & (A) & (B) & (AA) & $(\mathrm{AB})$ & (BB) & & & \\
\hline SAK & 150 & 0.90 & 0.10 & 105 & 45 & 0 & $0.3622^{\mathrm{NS}}$ & 0.2000 & 0.1806 \\
\hline AKK & 150 & 0.98 & 0.02 & 144 & 4 & 2 & $0.0023^{* *}$ & 0.0267 & 0.0521 \\
\hline AWS & 150 & 1.00 & 0.00 & 150 & 0 & 0 & monomorphic & 0.0000 & 0.0000 \\
\hline
\end{tabular}

$* * \mathrm{P}<0.01 ; \mathrm{NS}$ : Not significant

$* * \mathrm{P}<0.01 ; \mathrm{NS}$ : Önemsiz 
Table 2. Least Square Means ( \pm SEM) of milk traits in sampled sheep breeds.

Tablo 2. Örnekleme yapılan koyunlarda süt özelliklerine ait en küçük kareler ortalamaları $( \pm \mathrm{SH})$

\begin{tabular}{lcccc}
\hline Traits & \multicolumn{4}{c}{ Sheep breeds } \\
\hline Fat $(\%)$ & Sakiz & Awassi & Akkaraman & P value \\
Lactose (\%) & $7.066^{\mathrm{a}} \pm 0.586$ & $5.171^{\mathrm{b}} \pm 0.455$ & $4.121^{\mathrm{c}} \pm 0.381$ & $0.000^{* * *}$ \\
Protein (\%) & $5.419^{\mathrm{c}} \pm 0.425$ & $5.920^{\mathrm{b}} \pm 0.489$ & $6.113^{\mathrm{a}} \pm 0.491$ & $0.000^{* * *}$ \\
Milk yield (ml/day) & $6.435^{\mathrm{a}} \pm 0.571$ & $3.919^{\mathrm{c}} \pm 0.327$ & $4.029^{\mathrm{b}} \pm 0.335$ & $0.000^{* * *}$ \\
& $1.102^{\mathrm{a}} \pm 0.083$ & $1.051^{\mathrm{a}} \pm 0.078$ & $0.804^{\mathrm{b}} \pm 0.063$ & $0.000^{* * *}$ \\
\hline
\end{tabular}

$\overline{\mathrm{a}, \mathrm{b}, \mathrm{c}}$ Different letters indicate statistically significant.

a,b,c Farklı harfler istatistiksel olarak önemliliği göstermektedir.

$* * * \mathrm{P}<0.001$.

Table 3. Association of $\beta$ - $L G B$ genotypes with milk production traits in Sakiz sheep breeds.

Tablo 3. Sakız koyun ırkında $\beta-L G B$ genotipleri ile süt verim özellikleri arasındaki istatistiksel ilişki.

\begin{tabular}{|c|c|c|c|c|}
\hline \multicolumn{5}{|c|}{$\beta-L G B$ genotype } \\
\hline & AA & $\mathrm{AB}$ & $\mathrm{BB}$ & $\mathrm{P}$ value \\
\hline Milk yield (ml) & $1.034^{\mathrm{b}} \pm 0.016$ & $1.619^{\mathrm{a}} \pm 0.019$ & - & $0.000 * * *$ \\
\hline Fat $(\%)$ & $7.071^{\mathrm{a}} \pm 0.096$ & $4.937^{\mathrm{b}} \pm 0.079$ & - & $0.000 * * *$ \\
\hline Lactose (\%) & $5.478^{\mathrm{a}} \pm 0.013$ & $5.466^{\mathrm{a}} \pm 0.111$ & - & $0.712^{\mathrm{NS}}$ \\
\hline Protein $(\%)$ & $6.611^{\mathrm{a}} \pm 0.070$ & $6.278^{b} \pm 0.115$ & - & $0.000^{* * *}$ \\
\hline
\end{tabular}

*** means of sheep milk traits with different letters are significantly different, $\mathrm{P}<0.001 \mathrm{NS}$ : Not significant

*** Farklı harfler incelenen süt verim özellikleri bakımından istatistiksel olarak önemli farklılığın olduğunu göstermektedir, $\mathrm{P}<0.001$. NS: önemsiz ( \pm SEM).

study, the PCR-RFLP analysis of exon 2 of the $\beta-L G B$ gene shown interesting variations in the examined populations. In all examined breeds, the A allele occurred more frequent than $\mathrm{B}$ allele. For $\beta-L G B$ genotypes clear differences were observed between Sakiz and Akkaraman breeds. In the Akkaraman breed BB genotype was only shown two samples, for this reason association analyze has been applied the Sakiz breed. In the Sakiz breed carrying AB genotype had a greater milk yield than those with AA genotype; homozygous AA ewes higher milk protein and fat percentage when compared heterozygous $\mathrm{AB}$ animals. However, there were no statistically significant differences in lactose percentage.

As a sequence results, the comparison between nucleotide sequence of X12817 (sheep $\beta$-LGB gene) showed two variation points (g.37G $>\mathrm{T}$, g.121C $>\mathrm{A}$ ) were detected in all samples. In these variation point, g. $37 \mathrm{G}>\mathrm{T}$ variation can be determined by $R s a \mathrm{I}$ restriction enzyme, whereas g.121C >A variation cannot be determined by RsaI (Figure 2).

\section{Discussion and Conclusion}

The distribution of allele frequencies of $\beta-L G B$ gene showed that the frequency of allele A was higher than that of allele B in Sakiz, Akkaraman and Awassi breeds. The similar results were observed in Bavarian milk sheep (31), Latvian Darkhead (35), Massese (29), Pag Island sheep (19), Gentile di Puglia (8), Delle Langhe (21), some Polish (20) and Egyptian (25) sheep breeds (33).

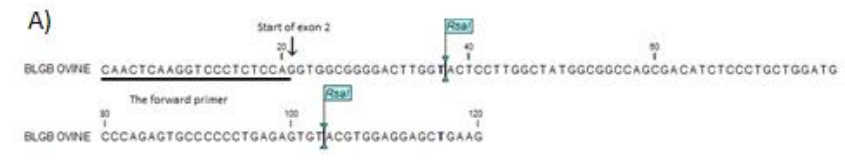

B)

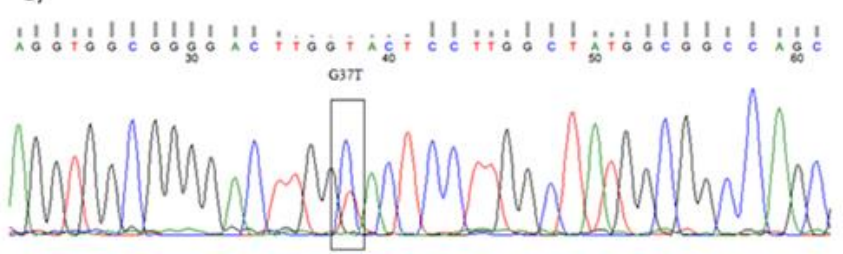

C)

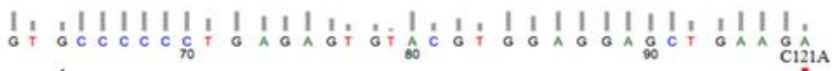

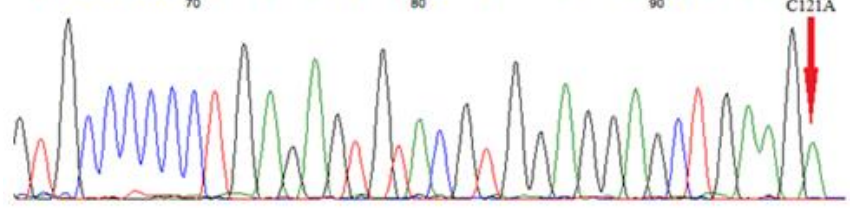

Figure 2. A) The structure of sheep $\beta-L G B$ gene and $R s a \mathrm{I}$ enzyme restriction sites. B) DNA sequence of genotype BB, g. $37 \mathrm{G}>\mathrm{T}$ variation point C) g. $121 \mathrm{C}>\mathrm{A}$ variation point in sheep $\beta-L G B$ gene.

Şekil 2. A) Koyun $\beta-L G B$ geni and $R s a \mathrm{I}$ restriksiyon enzimine ait kesim bölgeleri. B) BB genotipi, g.37G $>\mathrm{T}$ varyasyon noktas1 C) Koyun $\beta-L G B$ geninde g.121C>A varyasyon noktasi. 
Sakiz ewes with $\beta$-LGB genotype $\mathrm{AB}$ showed higher milk yield whereas lower fat and protein percentage than animals with genotype AA, this should be an effect of allele B. In this study, only two Akkaraman ewes were shown BB genotype. To explain the exact effect of allele $B$ a large number of animals would have to be studied.

However, according to Arora et al. (3) the B allele was the most frequent in native Indian sheep breeds as reported also in Valle del Belice (10), Sarda (26) and in Latxa, Manchega and Churra breeds (5). Schmoll et al. (32) reported that East Friesian ewes with the AA genotype had the greatest milk yield in the first lactation, whereas the $\mathrm{BB}$ ones yielded more milk in the following lactations. Similarly, Giaccone et al. (16) found that the AA genotype was associated with greater milk yield in Valle del Belice ewes.

On the other hand, Pietrola et al. (26) found no significant differences among genotypes in Sarda ewes and other studies point toward superiority of the B allele. Kawecka and Radko (20) found no associations between $\beta$ - $L G B$ genotypes and milk yield and composition in some Polish sheep breeds. Ramos et al. (27) observed higher milk yield in $\mathrm{AB}$ heterozygotes in Merino and Serra da Estrela sheep; Yousefi et al. (38) revealed significant associations between $\mathrm{AB}$ genotypes and higher milk fat and lactose percentages in indigenous $\mathrm{Zel}$ sheep; which are the similar of the results presented in this study for Sakiz and Akkaraman. Furthermore, similar observations were found for East Frisian Dairy sheep (17).

In our study, Awassi ewes was not shown polymorphism for the exon 2 of the ovine $\beta-L G B$ gene. But, Celik and Özdemir (7) reported that AB genotype was associated with higher lactose content in Awassi sheep. Also, Elmaci et al. (11) reported that the $\beta-L G B$ genotype $\mathrm{AB}$ was low and was not exceed $2 \%$ in Sakiz sheep, which is the opposite of the results presented in this study for Sakiz ewes.

According to Yousefi et al. (38) the inconsistency of the observed results compared to other studies may be ascribed to breed differences, population size, sampling, environmental factors and frequency distribution of genetic variants.

In this study, $\beta-L G B$ showed a significant effect on milk yield in the Sakiz ewes, but this influence was not detected in the Awassi breed. But further studies are necessary to comfirm the association reported here. Furthermore, we have reported for the first time g.121C>A SNPs of the $\beta-L G B$ gene for exon 2. The effect of this SNP of $\beta-L G B$ on milk traits or milk quality traits in these sheep breeds should be further investigated.

\section{Acknowledgements}

The project was supported by Scientific Research Projects Council of Firat University, VF.12.17.

\section{References}

1. Akcapinar H (2000): Koyun Yetiştiriciliği, Ismat Press, Ankara, pp 20-25.

2. Amigo L, Recio I, Ramos M (2000): Genetic polymorphism of ovine milk proteins: its influence on technological properties of milk-a review. Int Dairy J, 10,135-149.

3. Arora R, Bhatia S, Mishra BP, et al. (2010): Genetic polymorphism of the $\beta$-lactoglobulin gene in native sheep from India. Biochem Genet, 48, 304-311.

4. Barillet F (2007): Genetic improvement for dairy production in sheep and goats. Small Rumin Res, 70, 6075.

5. Barillet F, Arranz JJ, Carta A (2005): Mapping quantitative trait loci for milk production and genetic polymorphisms of milk proteins in dairy sheep. Genet Sel Evol, 37,109-123.

6. Carta A, Casu S, Salaris S (2009): Invited review: Current state of genetic improvement in dairy sheep. $\mathbf{J}$ Dairy Sci, 92,5814-5833.

7. Celik S, Ozdemir S (2006): $\beta$-Lactoglobulin variants in awassi and Morkaraman Sheep and their association with the composition and rennet clotting time of the milk. Turk $\mathrm{J}$ Vet Anim Sci, 30, 539-544.

8. Chessa S, Bolla P, Dario C, et al. (2003): Polimorfismi genetici lattoproteici nella razza ovina gentile di puglia: Monitoraggio mediante focalizzazione isoelectrica. Sci Tecn Lat Cas, 54,1-8.

9. Corral JM, Padilla JA, Izquierdo M, et al. (2013): Detection and genetic characterization of ovine CSN1S2B polymorphisms and their associations with milk production traits. Livest Sci, 153,10-19.

10. Di Stasio L, Portolano B, Todaro M, et al. (1997): Effect of ovine $\beta$-lactoglobulin phenotype on cheese yield and composition, in Proc. IDF Seminar Milk Protein Polymorphism. IDF Publishers, Brussels. pp. 324-327.

11. Elmaci C, Oner Y, Balcioglu SM (2006): Genetic polymorphism of $\beta$-lactoglobulin gene in native Turkish sheep breeds. Biochem Genet, 44, 7-8.

12. Erhardt G (1989): Genetic polymorphisms of $\alpha$ lactalbumin and $\beta$-lactoglobulin in sheep milk. Anim Genet, 20,76-77.

13. Excoffier L, Laval G, Schneider S (2006): Arlequin Version 3.01. An Integrated Software Package for Population Genetics Data Analysis. Computational and Molecular Population Genetics Lab (CMPG), Inst. of Zoology Univ. of Berne.

http://cmpg.unibe.ch/software/arlequin3/, Accessed 17 March 2014

14. FAO (Food and Agriculture Organization of The United Nations), Statistical Databases (http://faostat3.fao.org/home/E), Accessed 25 December 2014.

15. Feligini M, Parma P, Aleandri R, et al. (1998): $P C R$ RFLP test for direct determination of $\beta$-lactoglobulin genotype in sheep. Anim Genet, 29, 473-474. 
16. Giaccone P, Di Stasio L, Macciotta NPP, et al. (2000): Effect of betalactoglobulin polymorphism on related traits of dairy ewes milk analysed by repeated measures design. J Dairy Res, 67,443-448.

17. Giambra IJ, Brandt H, Erhardt G (2014): Milk protein variants are highly associated with milk performance traits in East Friesian Dairy and Lacaune sheep Small Rum Res, 121, 382-394.

18. Hall T (2007): BioEdit (http://www.mbio.ncsu.edu./BioEdit/bioedit.html). 12 Accessed 11 December 2014.

19. Ivancovic A, Dove P (2004): Polymorphism of $\beta$ lactoglobulin and aS1-casein genes in the Pag Island sheep. Acta Agric Slov, 84,121-130.

20. Kawecka A, Radko A (2011): Genetic polymorphism of $\beta$-lactoglobulin in sheep raised for milk production. J Appl Anim Res, 39, 68-71.

21. Leone P, Primiceri S, Fraghi A, et al. (1998): Polimorfismo dei loci as 1 e $\beta$-lactoglobulina in ovini di razza Sarda e Delle Langhe, in Proc. IV Congresso Nazionale Biodiversità Germoplasma Locale e Sua Valorizzazione, Alghero. pp. 8-11.

22. Moioli B, D'Andrea M, Pilla F (2007): Candidate genes affecting sheep and goat milk quality. Small Rumin Res, 68, 179-192.

23. Orford M, Hadjipavlou G, Tzamaloukas O, et al. (2012): A single nucleotide polymorphism in the acetylcoenzyme A acyltransferase 2 (ACAA2) gene is associated with milk yield in Chios sheep. J Dairy Sci, 95, 3419-3427.

24. Orford M, Tzamaloukas O, Papachristoforou C, et al. (2010): Technical note: A simplified PCR-based assay for the characterization of two prolactin variants that affect milk traits in sheep breeds. J Dairy Sci, 93, 5996-5999.

25. Othman OE, El Fiky SA, Hassan NA, et al. (2012): Genetic polymorphism of whey protein genes $\beta-L G$ and $\alpha$ LA in three Egyptian sheep breeds. J Appl Biol Sci, 6, 2530.

26. Pietrola E, Carta A, Fraghi A, et al. (2000): Effect of $\beta$ lactoglobulin locus on milk yield in Sarda ewes. Zoot Nutr Anim, 26, 129-133.

27. Ramos AM, Matos C, Bettencourt C, et al. (2002): Influence of aS1-casein, b-lactoglobulin and prolactin genotypes on milk production traits in two Portuguese sheep breeds, in 7th World Congress on Genetics Applied to Livestock Production, Montpellier. INRA, Paris.

28. Ramos AM, Matos CAP, Russo-Almeida PA, et al. (2009): Candidate genes for milk production traits in Portuguese dairy sheep. Small Rumin Res, 82, 117-121.
29. Rampilli M, Cecchi F, Giuliotti L, et al. (1997): The influence of $\beta$-lactoglobulin genetic polymorphism on protein distribution and coagulation properties in milk of Massese breed ewes, in Milk Protein Polymorphism. International Dairy Federation, Brussels, pp. 311-315.

30. Sambrook J, Fritsche F, Maniatis T (1989): Molecular Cloning: A Laboratory Manual. Cold Spring HarbourLab. Press, Cold Spring Harbour, New York.

31. Schlee P, Krause I, Rottmann O (1993): Genotyping of ovine $\beta$-Lg alleles $A$ and B using the PCR. Arch Tierz, 36, 519-523.

32. Schmoll F, Herget I, Hatzipanagiotou A, et al. (1999): Associations of beta-lactoglobulin variants with milk production, milk composition and reproductive performance in milk sheep. Wiener Tieraerztliche Monatsschrift, 86, 57-60.

33. Selvaggi M, Laudadio V, Dario C, et al. (2014): Investigating the genetic polymorphism of sheep milk proteins: a useful tool for dairy production. J Sci Food Agric, 94, 3090-3099.

34. Staiger EA, Thonney ML, Buchanan JW, et al. (2010): Effect of prolactin, $\beta$-lactoglobulin, and $\kappa$-casein genotype on milk yield in East Friesian sheep. J Dairy Sci, 93, 17361742.

35. Stambekov SZ, Shapiro YO, Mandrusova EE (1997): Milk protein polymorphism in Soviet Merino and Latvian Dark headed ewes and its connection with economically valuable characteristics. J Dairy Sci, 39, 6873.

36. Unal N, Akcapinar H, Atasoy F, et al. (2008): Milk yield and milking traits measured with different methods in Bafra sheep. Rev Med Vet, 159, 494-501.

37. Wu XL, MacNeil MD, De S, et al. (2005): Evaluation of candidate gene effects for beef backfat via Bayesian model. Genetica, 125, 103-113.

38. Yousefi S, Ahani Azari M, Zerehdaran S, et al. (2013): Effect of $\beta$-lactoglobulin and $\kappa$-casein genes polymorphism on milk composition in indigenous Zel sheep. Arch Tierz, 56, 216-224.

Geliş tarihi: 10.06.2015 / Kabul tarihi: 13.07.2015
Address for correspondence:
Dr. Özge Özmen
Ankara University, Faculty of Veterinary Medicine,
Department of Genetics, Ankara, Turkey.
e-mail: ozgeozmen@ankara.edu.tr 